GHANA JOURNAL OF DEPARTMENT OF HEALTH, PHYSICAL EDUCATION AND RECREATION, SPORTS AND DANCE (GJOHPERSD)

\author{
Volume 11, Year 2018
}

A JOURNAL OF THE DEPARTMENT OF HEALTH, PHYSICAL EDUCATION AND RECREATION (HPER)

UNIVERSITY OF CAPE COAST GHANA, WEST AFRICA 


\title{
Pre-service Teacher Preparation for Early Childhood Education in Ghana: A Review of Literature
}

\author{
Aaron Osafo-Acquah \\ Department of Basic Education University of Cape Coast \\ aosafo-acquah@ucc.edu.gh \\ 0551536656/0503177764
}

\begin{abstract}
As a result of the continued interest in the expansion of early childhood education opportunities in Ghana, questions have arisen about how to prepare teachers for work in this context. This literature review explores the state of pre service teacher preparation for early childhood education in Ghana. Findings from the review show that Ghana faces a lot of challenges including lack of trained teachers, poor infrastructure, and poorly developed teaching and learning.The first formal declaration to address early childhood education in Ghana came in the form of the Gold Coast Colony Education Department schedule of 1930, which included a syllabus for infant classes as part of a primary schedule. The syllabus included instruction based on games, physical exercises, spoken English, singing, and arithmetic (McWilliam, H.O.A., \& Kwamena-Po, M. A. (1975). After Ghana gained independence in 1957, the Education Act of 1961 was enacted to designate preschool as the responsibility of the Ministry of Education, and also declared compulsory basic education (Kindergarten-Middle school) as free for all children from age Four (4) to age Fifteen( 15). Four years later, the Nursery and Kindergarten Unit of the Ghana Education Service was created. The purpose of that unit was to develop preschools, nurseries, Kindergartens, as well as assist in the evaluation, control, and
\end{abstract}


Pre-service Teacher Preparation for Early

Children Education in Ghana

registration of these institutions. The idea of employing teaching staff who were trained teachers and professionals, led to the establishment of the National Nursery Teachers' Training Centre in Accra in 1965 to train early childhood personnel (Morrison 2002). By the year 1975, the Department of Social Welfare supervised 488 day care centres and the Ghana Education Service supervised 567 nursery schools and Kindergartens which enrolled 56,089 children. In an effort to regulate these early childhood centres and their programmes, the Department of Social Welfare established guidelines, which required centres to apply for permit and therefore register with the Department of Social Welfare. The Children's Act of 1989 was therefore established and put into effect.

Keywords: Pre-service, teacher preparation 


\section{Introduction}

Currently, there is collaboration among various groups and entities that supervise various early childhood development programmes. These groups include the Department of Social Welfare, $31^{\text {st }}$ December Women's Movement, Ghana Education Service, and the Ministry of Health (Republic of Ghana Ministry of Women and Children's Affairs,. It is believed that if all these groups and organizations cooperate with one another, the resources could be better utilized and therefore more facilities could be created to serve more students.

Once Early Childhood Education facilities were built, there must be teachers that had the background and training to provide adequate instruction. Utilising teachers that were trained at similar centres will also provide for a means of evaluating schools and day care centres, as well as providing a certain standard. To do this, the Ghana Education Service adopted the "train the trainer" method, and in September 1999 the Institute of Caregivers was opened to provide training for a fee. Presently, Colleges of Education, as well as the University of Cape Coast (UCC), and University of Education, Winneba (UEW), offer programmes in Early Childhood Education. According to the UNESCO International Bureau of Education Country profile report on Early Childhood Care and Education in Ghana (2006), among the 22,044 early childhood teachers, only $22.2 \%$ had received professional training. Despite the rapid expansion of preschool services, the quality of instruction was of great concern.

\section{Positioning the review of literature on pre service teacher preparation for early childhood education in the context of a global perspective}

As a result of the continued interest shown by government, the Ministry of Education, Ministry of Health, parents, and other stakeholders in the expansion of early childhood education opportunities, questions have arisen about how to prepare teachers 
Pre-service Teacher Preparation for Early

Children Education in Ghana

for work in this context. This review explored literature on preservice teacher preparation for early childhood education in Ghana.

Ghana's initial teacher training colleges (now known and called Colleges of Education) do not have adequate specialized coursework for preparation and development of early childhood teachers (Agbeyega \& Deku, 2011). This is because the nation's Universities, which serve as the training and preparation grounds for the Colleges, initially did not have programmes for preparing such teachers. According to Agbenyega and Deku (2011) majority of teachers received their early childhood teacher training through in-service programmes while on the job. The Ministry of Education's Nursery and Kindergarten Unit established in 1965 has been offering specialised early childhood teacher education programmes (MOE 2004). Given this commitment by government and the Ministry of Education, Agbenyega and Deku (2011) concluded that there was still much to be done in reaching the goal of a systematic early childhood pre service training programme for teachers needed in the area of early childhood education.

My search for appropriate articles open access and peer reviewed journals for the review focused on search items such as early childhood education, Ghana, Teacher Preparation, and Pre-service Teacher Preparation since 2009. The criteria for inclusion and exclusion of search terms for the literature review concentrated on only peer reviewed articles that have been published since 2009 .

According to Ghana's Ministry of Education (2004), the government of Ghana has set up a National Nursery Teachers' Training Centre where teachers who specialize in nursery education and nursery attendants are trained. The preschool or nursery teacher-training course lasts three months after which a certificate is awarded. The basic level initial teacher-training course in Colleges of Education lasts three years after which a teachers' diploma is awarded to successful candidates. In addition to the National Nursery Teacher Training Centre, the University of Cape Coast (UCC), and University of Education, Winneba, also provide a four - year degree programme in Early Childhood Education. 
Initial teacher education in Ghana (also known as pre service teacher training) takes place largely or exclusively in institutions of higher education such as the universities, or Colleges of Education. It may be organized according to two basic models. In the first model, a student first obtains a qualification in one or more subjects, often an undergraduate Bachelor's degree from the traditionally non-education oriented Universities such as University of Ghana, Legon, or Kwame Nkrumah University of Science and Technology. Subsequent to securing employment as a teacher, the student continues schoolwork over an additional twoyear period either by Distance Education, or by Sandwich during which period, such candidates take an eight-week residential course in education related courses in any of the education oriented Universities such as University of Cape Coast (UCC), or University of Education, Winneba (UEW) resulting in qualification to teach. The eight-week residential course is done for two consecutive years. In the alternative model, a student simultaneously studies one or more subjects, and the ways of teaching that subject concurrently, leading to a combined Bachelor's degree and a teaching credential from the education oriented Universities thereby qualifying as a teacher of that subject.

Concluding their paper on "Building new identities in teacher preparation for inclusive education in Ghana", Agbenyega and Deku (2011) situated their paper in the general lack of adequate teacher preparation including teachers in early childhood education for Ghana's basic schools. They therefore proposed a new framework for teacher preparation in the light of the report of the Presidential Commission on the review of education in Ghana (MOE 2004), The report stated the objective of teacher education as the training and development of the right type of teacher who is competent, committed, and dedicated. Such a teacher should be able to:

1. Develop attitudes, values, and dispositions that create a conducive environment for quality teaching and learning in schools.

2. Apply, extend, and synthesize various forms of knowledge. 
Pre-service Teacher Preparation for Early

Children Education in Ghana

3. Facilitate learning and motivate individual learners to fully realize their potential.

4. Promote inclusive education at all levels.

5. Adequately prepare the learner to participate fully in the national development effort.

The question of what knowledge, attitudes, behaviours, and skills an early childhood education teacher should possess is a subject of much debate in Ghana. This is because early childhood education is a unique area that requires a distinct set of skills in its teacher preparation to enable such teachers perform well. However, generally, teacher education curricula can be broken down into four major areas:

1. Foundational knowledge in education - related aspects of philosophy of education, history of education, educational psychology, and sociology of education.

2. Skills in assessing student learning and supporting the learning of all subjects, using technology to improve teaching and learning, and supporting students with special needs.

3. Content area and methods knowledge, and skills often including ways of teaching and assessing a specific subject in which case this area may overlap with the first (foundational) level.

There is increasing debate about how to know in advance what kinds of knowledge and skills Ghanaian children need when they enter adult life, and or what the needs of society would be since the dynamics of politics in Ghana keep changing. It therefore becomes harder to know what kinds of knowledge and skills teachers should have. There is however extensive knowledge and research about the developmental needs of young children and therefore there is a comprehensive understanding of young children and their development that should inform the necessary skills sets needed by teachers. Increasingly, emphasis is been placed upon developing social skills and social competencies, which cut across traditional subject boundaries. 
According to the Ghana Education Service (GES), Ghana has made tremendous gains in the area of early childhood education, but there are significant challenges in scaling up the quality of the early childhood education programme. In line with the recommendations of the Dakar World Forum for Education, and the Millennium Development Goals (MDGs), the government of Ghana mainstreamed Kindergarten into basic education, and through the Education Strategic Plan (ESP), 2010 - 2020, has prioritized expanding and improving comprehensive early childhood care and education. (GES 2016). In accordance with this provision, a five - year operational plan for transforming the sector was set up that included teacher training, pedagogy, and parental involvement. In the plan, twenty seven thousand $(27,000)$ Kindergarten teachers were to receive mass transformational training based on a new vision and pedagogy of activity based learning, and child - centred, child - led approaches. Colleges of Education, the University of Cape Coast, and University of Education, Winneba, were to turn out each year two thousand, and three hundred $(2,300)$ early childhood education specialist trained teachers, and finally, an established assessment, monitoring, and evaluation put in place.

The Ghana Education Service as part of the Education Reform of 1987, and the report of the President's Committee of 2004 has organized several seminars and conferences with stakeholders on what the most effective strategies for educating and training the nation's teachers. Reports from such conferences and seminars have shown that policy makers teacher educators, and other stakeholders seek a systematic and comprehensive preparation and training that meet the requirements for efficient teacher performance.

\section{Significance of the Review}

The early childhood sector in Ghana faces many challenges including lack of trained teachers, poor infrastructure, poorly developed teaching and learning, and issues regarding the 
Pre-service Teacher Preparation for Early

Children Education in Ghana

implementation of language policy among others. The Children's Act (1998), and the 2004 ECCD Policy which are strengthened by the 1992 Constitution of the Republic of Ghana and demonstrate the commitment to the promotion of pre service teacher preparation for early childhood education. The focus of teacher preparation and teacher education is on optimizing pre service teachers' knowledge of children's total development in the areas of personal awareness, emotional well - being, socialization, communication, cognitive, and perceptual motor skills.

Situating the review in the broader scholarly literature of early childhood education, evidence has shown that Kindergarten and for that matter early childhood education was developed as a non academic approach to early learning and education, and the belief in the importance of connecting learning to real life. In Ghana, the Basic Education Act of 2004 cites early childhood education, which has to do with pre primary education given to children between ages one and five, as an integral part of basic education. It indeed represents the first important step in achieving the goals of Education For All (EFA).

The authors of the various works have reflected on the work of teachers, both in their preparation and in terms of their on-going professional learning and development. The indications were clear in their works that there should be culturally responsive and grounded programmes for teacher education to enable teachers gain greater insight into the diversities that are apparent in children's lives so that they are able to provide contexts in which individuals feel that their identity is honoured and respected. What this means in the Ghanaian context is that, curricula and programmes for early childhood teacher preparation should be context specific to the needs and cultural aspirations of the communities from which the children are found. It must recognize the diverse qualities of children and their families in a global context of educational opportunities for children. 
Policy makers including the Ghana Education Service, Ministry of Education, and the Ministry of Women and Children's Affairs are awakened by the call for better and efficient ways of preparing pre service teachers for early childhood education. Stakeholders including parents, and non-governmental organizations (NGOs) also have a responsibility to sit up and ensure that they all put their hands to the wheels for the preparation of pre service teachers for early childhood education.

Teacher educators as well as pre service trainees also have to view the responsibility place on their shoulders as a call to national duty and to perform to the best of their ability. The Ministry of Education is the sector responsible for education at all levels (Kindergarten- University), while the Ghana Education Service is responsible for pre-tertiary education. Non-governmental organizations are bodies, agencies and nstituitions that are privately owned, and do enjoy government subvention.

\section{Conclusion}

In accordance with the provisions of the Education Strategic Plan (ESP), a five-year plan to transform teacher preparation, pedagogy, and government involvement in early childhood education has been formulated. There is also a commitment on the part of government towards reaching the goal of a systematic early childhood training programme as part of the Free Compulsory Universal Basic Education (FCUBE) agenda. The Early Childhood Care and Development (ECCD) Policy of Ghana focuses on building the capacity of ECCD practitioners and instructors among its goals and objectives. To achieve this, teacher education institutions such as the University of Cape Coast (UCC), University of Education, Winneba (UEW), and the Colleges of Education need to expand and maximize use of their facilities, as well as prepare researchers and early childhood teachers and leaders who can assume critical roles in advancing early childhood education throughout the nation. The importance and position of a highly prepared team of teachers for early childhood education in 
Pre-service Teacher Preparation for Early

Children Education in Ghana

Ghana cannot be overemphasized, and everything must be done to ensure that the state of pre service teacher preparation for early childhood education in Ghana is improved.

\section{References.}

Agbenyega, J. S., \& Sunata Kibthong (2011). Early childhood incIusion: a post colonial analysis of preservice teachers professional development and pedagogy in Ghana. Contemporary Issues in Early childhood, 12 (4), $403-414$.

Agbenyega, J. \& Deku, P. (2010). Building new identities in teacher preparation for Inclusive education in Ghana. Current Issues in Education, 14, (1). Retrieved from http://cie. Asu.edu/in Ghana. Academia.edu

Dillard, C. B. (2009). "I am because we are: increasing educational opportunity for early Childhood education in Ghana, West Africa". Race/Ethnicity: Multidisciplinary Global Perspectives. 2.(2), 243-257. Project Muse. Web. 15 Nov. 2009

Ghana Education Service. (2016). Summary data for Public Kindergartens in Cape Coast Metropolitan. Cape Coast: Ghana.

Ministry of Education. (2004). Report of the president's committee on review of education reforms in Ghana (AnamuahMensah Report), Accra: Ministry of Education, Accra.

Morrison, J. W. (2002). Teacher training in early childhood education: The case of Ghana. West Africa. Journal of Early Childhood Teacher Education, 23, 315-31.

McWilliam, H.O.A., \& Kwamena-Po, M. A. (1975). The development of education in Ghana: An outline. London: Longman Group Ltd. Republic of Ghana Ministry of Women and Children's Affairs. (n.d.). 
Early childhood care and development policy. Retrieved from http://mowacghana.net/files/eccdp.pdf

Rita Chawla-Duggan R. (2013). Education quality and social justice in global south: challenges for policy, practice, and research. Quality and early childhood care and education. Lessons from India and Ghana. Retrieved fromhttp://usf.catolog.fcla.edu/sf.jsp? St=SFo31815577 $\&$ ix $=$ pm \& $1=\mathrm{O} \& \mathrm{~V}=\mathrm{D} \& \mathrm{PM}=1$. P. 91

Vogt, Shin, Mishra, \& Gibson(2011) Teachers assessment of TPACK: where are we and what is needed?. In Society for Information Technology and Teacher Education International conference. (Vol. 2011, No. 1, pp. 4422-4426). 